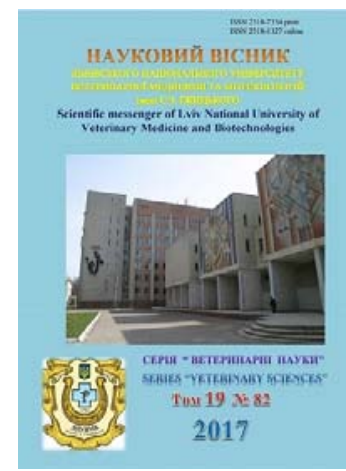

Науковий вісник Львівського національного університету ветеринарної медицини та біотехнологій імені С.З. Гжицького

Scientific Messenger of Lviv National University of Veterinary Medicine and Biotechnologies

doi:10.15421/nvlvet8207

ISSN 2518-7554 print

ISSN 2518-1327 online

http://nvlvet.com.ua/

\title{
Особливості локалізації лімфоїдної тканини в імунних утвореннях стінки кишечнику, дивертикулі меккеля і сліпокишкових дивертикулах качок
}

\author{
Т.А. Мазуркевич, В.Т. Хомич \\ mazur@faust.kiev.ua, gistology_chair@nubip.edu.ua \\ Національний університет біоресурсів і природокористування Украӥни, \\ вул. Героїв Оборони, 15, м. Київ, 03041, Україна
}

\begin{abstract}
Лімфоїдна тканина, асоційована зі слизовими оболонками, займає особливе місие в імунній системі, формуючи периий захисний бар'єр проти антигенів, котрі потрапляють в організм з кормом та повітрям. У птахів до 70\% лімфоїдної тканини, яка формує паренхіму периферичних органів імуногенезу, локалізовано в слизовій оболонці стінки трубчастих органів травлення. Останнім часом у спеціальній літературі з'явилися повідомлення, щзо лімфоїдна тканина в трубчастих органах травлення водоплавної птиці (гуси, мускусні качки) може бути локалізована не тільки у слизовій оболонці, а й у м'язовій. У зв'язку з ичим метою дослідження було встановити особливості локалізації лімфоїдної тканини в імунних утвореннях (плямки Пейєра) стінки кишечнику качок, дивертикулі Меккеля та сліпокишкових дивертикулах в постнатальному періоді онтогенезу. Встановлено, що лімфоїдна тканина в плямках Пейєра кишечнику, дивертикулі Меккеля та сліпокишкових дивертикулах качок розташована в слизовій і м'язовій оболонках їх стінки. 3 добового віку качок лімфоїдна тканина виявляється у слизовій оболониі досліджених нами структур та в м'язовій оболониі сліпокишкових дивертикулів, а в м'язовій плямок Пейєра кишечнику і дивертикула Меккеля - з 10-20-добового.

Повна морфофункиіональна зрілість лімфоїдної тканини у слизовій оболонці плямок Пейсра кишечнику настає у 15 добовому вічі качок, лімфоїдної тканини слизової оболонки дивертикула Меккеля - у 20-добовому віці та сліпокишкових дивертикулів - у 10-добовому вічі. Повної морфофункціональної зрілості лімфоїдна тканина м'язової оболонки плямок Пейєра кишечнику досягає у 15-20-добовому вічі качок, лімфоїдна тканина м'язової оболонки дивертикула Меккеля - у 25 добовому віці та сліпокишкових дивертикулів - у 10-добовому віщі.

Площа лімфоїдної тканини у слизовій оболонці плямок Пейєра дванадчятипалої і клубової кишки збільшується до 210добового віку качок, а порожньої кишки - до 150-добового. У м'язовій оболониі названих структур лімфоїдна тканина займає найбільшу площу в 150-добових качок. Площа лімфоїдної тканини у слизовій оболонщі сліпих кишок збільшується до 90-добового віку, а у м'язовій - до 240-добового.

Максимальну площу лімфоїдна тканина в слизовій оболонці дивертикула Меккеля займає у 20-добових качок, а в сліпокишкових дивертикулах - в 180-добових. В м'язовій оболонці иих структур лімфоїдна тканина найбільшу площу займає в 150-добових качок.

Ключові слова: качки, кишечник, тонка кишка, товста кишка, дванадиятипала кишка, порожня кишка, клубова кишка, сліпі кишки, дивертикул Меккеля, сліпокишкові дивертикули, плямки Пейєра, лімфоїдна тканина, дифузна лімфоїдна тканина, передвузлики, первинні лімфоїдні вузлики, вторинні лімфоїдні вузлики.
\end{abstract}

\section{Особенности локализации лимфоидной ткани в иммунных образованиях стенки кишечника, дивертикула меккеля и слепокишечных дивертикулах уток}

\author{
Т.А. Мазуркевич, В.Т. Хомич
}

mazur@faust.kiev.ua, gistology_chair@nubip.edu.ua

\section{Citation:}

Mazurkevych, T.A., Khomych, V.T. (2017). Location features of lymphoid tissue in immune formations of the intestine, meckel's diverticulum and apical diverticula walls in ducks. Scientific Messenger LNUVMB, 19(82), 30-35. 
Национальньий университет биоресурсов и природопользования Украиньл, ул. Героев Обороны, 15, г. Киев, 03041, Украина

Лимфоидная ткань, ассочиированная со слизистыми оболочками, занимает особое место в иммунной системе, формируя первый защитный барьер против антигенов, которые попадают в организм с кормом и воздухом. У птии до $70 \%$ лимфоидной ткани, которая формирует паренхиму периферических органов иммуногенеза, локализовано в слизистой оболочке стенки трубчатых органов пищеварения. В последнее время в специальной литературе появились сообщения, что лимфоидная ткань в трубчатых органах пищеварения водоплавающей птищы (гуси, мускусные утки) может быть локализована не только в слизистой оболочке, но и в мышечной. В связи с этим иелью исследования было установить особенности локализации лимфоидной ткани в иммунных образованиях (пейеровы бляшки) стенки кишечника уток, дивертикуле Меккеля и слепокишечных дивертикулах в постнатальном периоде онтогенеза. Установлено, что лимфоидная ткань в пейеровых бляшках кишечника, дивертикуле Меккеля и слепокишечных дивертикулах уток расположена в слизистой и мышечной оболочках их стенки. С суточного возраста уток лимфоидная ткань выявляется в слизистой оболочке исследованных нами структур и в мышечной оболочке слепокишечных дивертикулов, а в мышечной пейеровых бляшек кишечника и дивертикула Меккеля-с 10-20-суточного.

Полная морфофункииональная зрелость лимфоидной ткани в слизистой оболочке пейеровых бляшек кишечника наступает в 15-суточном возрасте уток, лимфоидной ткани слизистой оболочки дивертикула Меккеля - в 20-суточном возрасте и слепокишечных дивертикулов - в 10-суточном. Полной морфофункииональной зрелости лимфоидная ткань мышечной оболочки пейеровых блямек кишечника достигает в 15-20-суточном возрасте уток, лимфоидная ткань мышечной оболочки дивертикула Меккеля - в 25-суточном возрасте и слепокишечных дивертикулов - в 10-суточном возрасте.

Площадь лимфоидной ткани в слизистой оболочке пейеровых блямек двенадцатиперстной и подвздошной кишки увеличивается до 210-суточного возраста уток, а тощей кишки - до 150-суточного. В мышечной оболочке указанных структур лимфоидная ткань занимает наибольщую площадь у 150-суточных уток. Площадь лимфоидной ткани в слизистой оболочке слепых кишок увеличивается до 90-суточного возраста, а в мышечной - до 240-суточного.

Максимальную площадь лимфоидная ткань в слизистой оболочке дивертикула Меккеля занимает у 20-суточных уток, а в слепокишечных дивертикулах - в 180-суточных. В мышечной оболочке этих структур лимфоидная ткань наибольшую пломадь занимает у 150-суточных уток.

Ключевые слова: утки, кишечник, тонкая кишка, толстая кишка, двенадиатиперстная кишка, тощая кишка, подвздошная кишка, слепье кишки, дивертикул Меккеля, слепокишечные дивертикуль, пейеровы блятки, лимфоидная ткань, диффузная лимфоидная ткань, предузелки, первичные лимфоидные узелки, вторичные лимфоидные узелки.

\title{
Location features of lymphoid tissue in immune formations of the intestine, meckel's diverticulum and apical diverticula walls in ducks
}

\author{
T.A. Mazurkevych, V.T. Khomych \\ mazur@faust.kiev.ua, gistology_chair@nubip.edu.ua \\ National University of Life and Environmental Sciences of Ukraine, \\ Heroyiv Oborony Str., 15, Kyiv, 03041, Ukraine
}

Mucous associated lymphoid tissue has a special place in the immune system, forming the first protective barrier against antigens that enter the body with food and air. In birds $70 \%$ of lymphoid tissue that forms the parenchyma of peripheral immune organs localized in the mucosa of tubular digestive organs. Recently, in the literature there have been reports that lymphoid tissue in tubular digestive organs of waterfowl (geese, musk ducks) can not be localized only in the mucosa, but also in muscularis. In this context, the aim of the study was to determine the features of lymphoid tissue localization in immune formations (Peyer's patches) of the intestine wall of ducks, Meckel diverticulum and apical diverticula in postnatal period ontogenesis. Established that lymphoid tissue in Peyer's patches of duck intestine, Meckel's diverticulum and apical diverticula located in the mucosa and muscularis of the wall. From the one-day age of duck, the lymphoid tissue is found in the mucosa of all investigated structures and in the muscularis of the apical diverticula, and in the muscularis of Peyer's patches of the intestine and the Meckel's diverticulum-from 10-20-days of age.

The complete morphofunctional maturity of the lymphoid tissue of mucosa Peyer's patches of intestine is reached in the 15 daysage of duck, the lymphoid tissue of the mucosa of the Meckel diverticulum - in 20-day age, and in the apical diverticula-in 10-day age. The complete morphofunctional maturity of the lymphoid tissue of muscularis Peyer's patches of intestine is reached in the 1525 days-age of duck, the lymphoid tissue of the muscularis of the Meckel diverticulum - in 25-day age, and in the apical diverticulain 10-day age.

Area of lymphoid tissue in the mucosa of duodenal and ileum Peyer's patches increased to 210-day-old ducks and jejunum - to 150-day-old age. Lymphoid tissue occupies the largest area in 150-day ducks in the muscularis of these structures. Area of lymphoid tissue in the mucosa of cecal Peyer's patches increased to 90-day-old ducks, and in the muscularis - to 240-day-old age.

Lymphoid tissue in the mucosa of Meckel's diverticulum takes up the largest area in 20-day-old ducks, in apical diverticula-in 180-day-old. In the muscularis of these structures, lymphoid tissue occupies the largest area in 150-day ducks.

Key words: Ducks, intestine, small intestine, large intestine, duodenum, jejunum, ileum, ceca, Meckel diverticulum, apical diverticula, peyer's patches, lymphoid tissue, diffuse lymphoid tissue, prenodules, primary lymphoid nodules, secondary lymphoid nodules

\section{Ветуп}

Особливе місце в імунній системі відводиться лімфоїдній тканині, асоційованій зі слизовими оболон- ками (mucous associated lymphoid tissue - MALT). Вона утворює основу агрегованих (плямки Пейєра) та поодиноких лімфоїдних вузликів кишечнику, червоподібного відростка, дивертикула Меккеля, лімфоїд- 
ного глоткового кільця Пирогова-Вальдейєра, гортанних мигдаликів і розташована також у стінці бронхів і трубчастих сечо-статевих органів. За регіональними ознаками виділяють лімфоїдну тканину травного каналу (gastrointestinal associated lymphoid tissue GALT) та лімфоїдну тканину дихальних шляхів (bronchus associated lymphoid tissue - BALT) (Brandtzaeg, 1984; Surjan, 1987; Day and Schultz, 2014; Kaushansky et al., 2015). Структури, якими вона утворена, формують перший захисний бар'єр проти антигенів, котрі потрапляють в організм 3 кормом та повітрям. У птахів до 70\% лімфоїдної тканини, яка формує паренхіму периферичних органів імуногенезу, локалізовано в стінках органів травлення. Це пов'язано $з$ тим, що переважна більшість антигенів в організм птахів надходить саме через органи травлення. Попередніми нашими дослідження (Khomych and Mazurkevych, 2012; Khomych and Mazurkevych, 2013), а також дослідженнями інших авторів (Kitamura et al., 1976; Georgescu et al., 2007) встановлено, що в імунних (лімфоїдних) утвореннях органів травного каналу водоплавної птиці (гуси, мускусні качки) лімфоїдна тканина може бути розміщена не тільки в їх слизовій оболонці, а й у м'язовій і серозній. У зв'язку з цим локалізація лімфоїдної тканини та її структура в імунних утвореннях стінки кишечнику водоплавної птиці потребує додаткових досліджень і уточнень.

Метою дослідження було вивчити особливості локалізації лімфоїдної тканини в імунних утвореннях стінки кишечнику, дивертикулі Меккеля і сліпокишкових дивертикулах качок.

\section{Матеріал і методи досліджень}

Матеріал для дослідження відібрали від бройлерних качок Благоварського кросу віком 1, 5, 10, 15, 20, 25, 30, 60, 90, 120, 150, 180, 210, 240 діб (по 4-6 качок кожного віку). Качок утримували в умовах, наближених до умов промислових комплексів. Їх годували спеціально приготовленими для такого віку стандартними комбікормами. Профілактичних щеплень проти інфекційних хвороб качкам не проводили. Усі втручання та забій птахів проводилися 3 дотриманням вимог «Свропейської конвенції про захист хребетних тварин, які використовуються для експериментальних і наукових цілей» (Страсбург, 1986) та ухвали Першого національного конгресу з біоетики (Київ, 2001).

При виконанні роботи використовували макроскопічні та гістологічні методи морфологічних досліджень (Avtandilov, 1990; Horalskyj et al., 2005).

Макроскопічними методами визначали кількість i топографію плямок Пейєра (ПП) та їх розміри і розміри дивертикула Меккеля. Для цього використовували штангенциркуль і сантиметрову лінійку.

Гістологічними дослідженнями встановлювали особливості мікроскопічної будови досліджуваних об'єктів, різновиди форм і топографію лімфоїдної тканини, яка формує їх основу. Матеріал для гістологічних досліджень фіксували у 10\% водному розчині нейтрального формаліну і заливали у парафін. 3 виготовлених блоків, за допомогою полозкового мікротома, готовили серійні зрізи товщиною 8-15 мкм, які фарбували гематоксиліном і еозином, за ван Гізоном, за Вейгертом, за Стідменом та імпрегнували за Келеменом.

Виготовлені гістологічні препарати досліджували за допомогою світлових мікроскопів МБС-2, МБИ-16, «Біолам» і «Olimpus». Статистичну обробку результатів проводили у табличному процесорі Exel-2010.

\section{Результати та їх обговорення}

До імунних утворень кишечнику качок, які видимі неозброєним оком, відносять ПП, дивертикул Меккеля і сліпокишкові дивертикули.

Попередніми нашими дослідженнями (Маzurkevych, 2013; Mazurkevych, 2014) встановлено, що імунні утворення 12-палої і клубової кишки качок представлені по одній ПП, а в порожній - трьома. Варто зазначити, що до 15-добового віку птиці їх топографію і розміри макроскопічно можна добре встановити лише за допомогою методу Хелмана. У качок старшого віку ПП виявляються візуально без застосування спеціальних методів. Розміри ПП дванадцятипалої кишки збільшуються до 150-добового віку, клубової кишки - до 120-добового віку, а порожньої - до 120-150-добового віку.

У сліпих кишках качок досліджених нами вікових груп чітко сформованих мигдаликів, подібних до таких мигдаликів сліпих кишок курей, ми не виявили. Разом $з$ тим у їх стінці є велика кількість ПП (рис. 1). Частина із них розташована в основі кишок ланцюжком. Довжина ланцюжка ПП лівої сліпої кишки більша, ніж правої, а ширина ланцюжка ПП правої сліпої кишки більша, ніж лівої. 3 віком качок лінійні параметри ланцюжків обох кишок змінюються, збільшуючись до 120-150-добового віку.

Відомо, що дивертикул Меккеля (ДМ) є рудиментом протоки жовткового мішка, яка з'єднувала його 3 порожниною порожньої кишки. Він має вигляд трубочки булавоподібної форми, яка лежить на порожній кишці. Його макроморфометричні показники збільшуються до 120-150-добового віку качок.

Сліпокишковий (апікальний) дивертикул - це конусоподібне закінчення сліпої кишки, в стінці якого локалізована лімфоїдна тканина. Лінійні параметри (довжина і найбільша товщина) дивертикула правої та лівої сліпих кишок неоднакові. Ці показники правого сліпокишкового дивертикула в більшості вікових груп качок більші, ніж такі лівого дивертикула.

Мікроскопічно стінка тонкої і товстої кишок у місці розташування ПП та сліпокишкових дивертикулів має таку ж будову як і в інших ділянках. Тобто вона утворена слизовою, м'язовою та серозною оболонками. Слизова оболонка кишечнику сформована чотирма шарами - епітелієм, власною пластинкою, м'язовою пластинкою та підслизовою основою. М'язова пластинка розвинена слабо. У дванадцятипалій кишці підслизова основа не містить дуоденальних залоз, як така у ссавців. М'язова оболонка представлена двома шарами гладкої м'язової тканини: сильно розвиненим внутрішнім циркулярним та зовнішнім поздовжнім. Серозна оболонка тонкої кишки утворена пухкою волокнистою сполучною тканиною, яка 
вкрита мезотелієм. Подібну будову має і стінка дивертикула Меккеля. Тільки в його слизовій оболонці

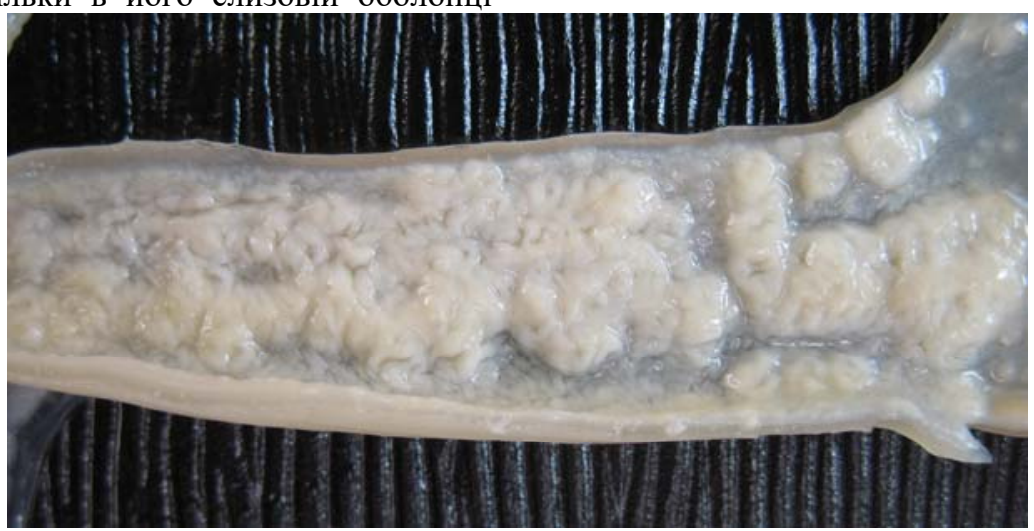

Рис. 1. Плямки Пейєра сліпої кишки качки віком 120 діб (просвітлення за Хелманом)

Лімфоїдна тканина (ЛТ) в ПП тонкої і товстої кишки в качок усіх досліджених вікових груп міститься у слизовій оболонці і, починаючи з 10-добового віку птиці, ще й у м'язовій оболонці дванадцятипалої, клубової та сліпих кишок та 3 20-добового віку в м'язовій оболонці порожньої кишки. У слизовій оболонці вона міститься в їі власній пластинці та підслизовій основі (рис. 2). При цьому лімфоїдні клітини інфільтрують епітелій ворсинок слизової оболонки і епітелій крипт. Ці клітини виявляються і в просвітах останніх.

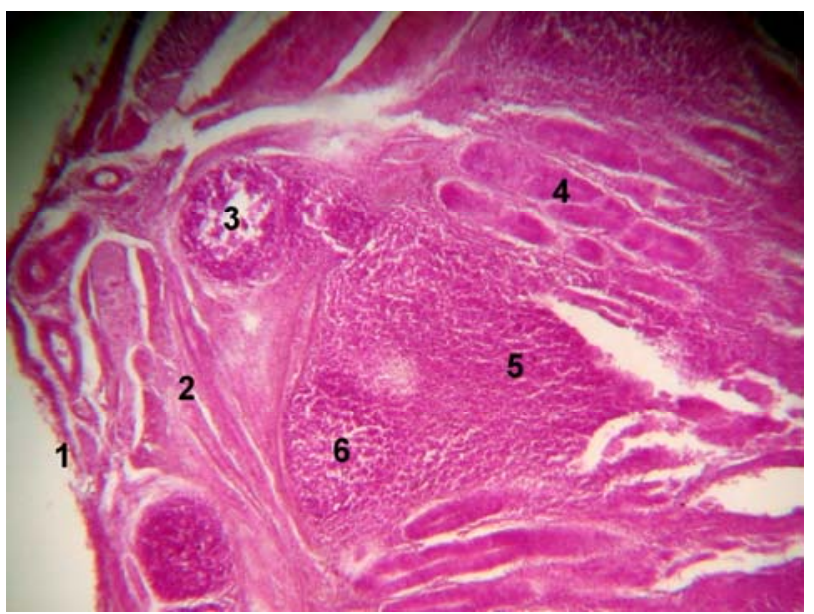

Рис. 2. Стінка плямки Пейєра дванадцятипалої кишки качки віком 30 діб:

1 - серозна оболонка; 2 - м'язова оболонка; 3 - вторинний лімфоїдний вузлик м'язової оболонки;

4 - крипти; 5 - дифузна лімфоїдна тканина; 6 - вторинний лімфоїдний вузлик слизової оболонки. Фарбування гематоксиліном та еозином, $\times 40$

Як відомо (Day and Schultz, 2014), ЛТ має чотири рівні структурної організації, які виникають у ній послідовно. Це дифузна лімфоїдна тканина (ДЛТ), передвузлики, первинні лімфоїдні вузлики (ПЛВ) i вторинні лімфоїдні вузлики (ВЛВ). Наявність усіх рівнів структурної організації лімфоїдної тканини свідчить про їі повну морфофункціональну зрілість і відповідно зрілість органів імуногенезу та імунних утворень, основу яких вона утворює. За даними на- ших досліджень, повна морфофункціональна зрілість ПП кишечнику, тобто здатність їх дати повноцінну відповідь на дію антигенів, наступає у качок віком 15 діб.

Площа, яку займає ЛТ у слизовій оболонці ПП дванадцятипалої кишки збільшується до 210-добового віку качок $(64,63 \pm 1,28 \%)$, порожньої - до 150 добового $(71,28 \pm 1,77 \%)$ і клубової - до 210 добового віку $(82,69 \pm 1,14 \%)$. А в ПП сліпих кишок цей показник досягає максимального значення $(46,43 \pm 1,78 \%)$ вже у 15 -добової птиці. У птиці старшого віку вміст ЛТ у слизовій оболонці ПП зменшується. Зі збільшенням віку качок змінюється і площа в ПП окремих рівнів структурної організації лімфоїдної тканини.

Як ми відмітили вище, ЛТ у ПП тонкої кишки качок виявляється не тільки у їх слизовій оболонці, а й у м'язовій. У м'язовій оболонці ПП дванадцятипалої, клубової та сліпих кишок вона реєструється у качок, починаючи з 10-добового віку, а порожньої - $з 20$ добового віку. Розміщена ЛТ локально у внутрішньому (циркулярному) шарі м'язової оболонки. Місцями вона має безпосередній зв'язок з ЛТ слизової оболонки (рис. 3). Площа ЛТ м'язової оболонки ПП тонкої кишки збільшується до 150-добового віку качок $(41,31 \pm 1,13-45,28 \pm 2,48 \%)$. У птиці старшого віку цей показник значно зменшується. У сліпих кишках вміст ЛТ м'язової оболонки ПП збільшується постійно і у 240-добових качок займає $36,72 \pm 0,68 \%$ iii площі. У ЛТ м'язової оболонки ми виявили тільки три рівні ії структурної організації: ДЛТ, ПЛВ та ВЛВ. Останні реєструються у м'язовій оболонці ПП дванадцятипалої кишки, починаючи з 15-добового віку качок, ПП порожньої і клубової кишки - 320 добового, ПП сліпих кишок - з 25-добового. У качок віком від 60 до 240 діб ВЛВ - це єдиний рівень структурної організації ЛТ м’язової оболонки.

У стінці ДМ качок ПП відсутні. ЛТ виявляється в iii слизовій і м'язовій оболонках. У слизовій оболонці вона реєструється в качок усіх досліджених вікових груп. Її площа збільшується до 20-добового віку $(59,88 \pm 0,29 \%)$. ЛТ слизової оболонки ДМ має усі рівні структурної організації у качок віком від 20 до 120 діб (рис. 4). У птиці старшого віку в слизовій 
оболонці виявляються тільки ДЛТ і ВЛВ. ЛТ в м'язовій оболонці ДМ реєструється у качок, починаючи з їх 15-добового віку. У своєму складі вона має ДЛТ, яка виявляється у птиці віком від 15 до 30 діб, ПЛВ і ВЛВ. Останні формуються у качок, починаючи з 25-добового віку. Цей рівень структурної організації ЛТ у м'язовій оболонці ДМ є єдиним у качок віком від 60 до 240 діб. Площа, яку займає ЛТ в м'язовій оболонці ДМ, збільшується до 150-добового віку качок.

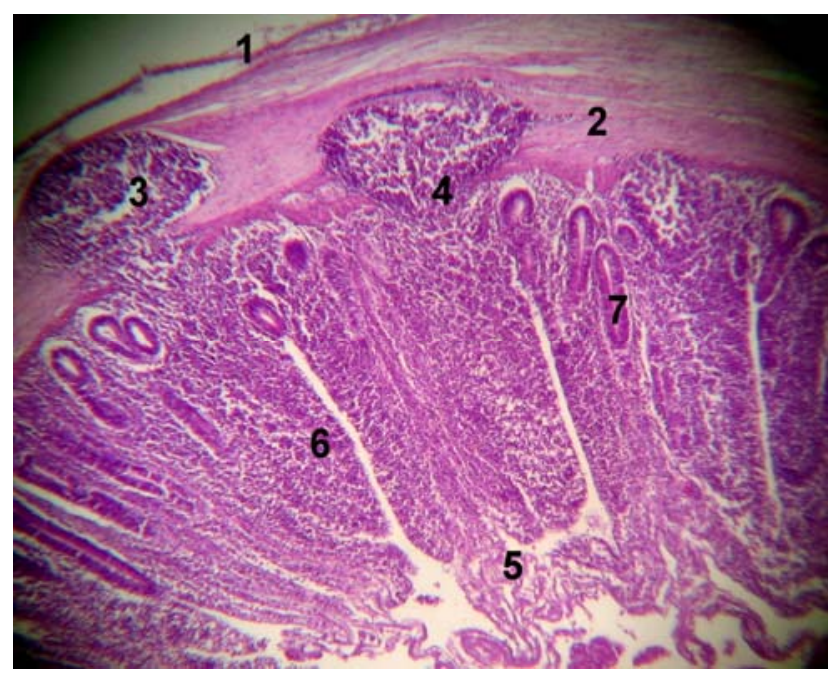

Рис. 3. Стінка плямки Пейсра порожньої кишки качки віком 20 діб:

1 - серозна оболонка; 2 - м'язова оболонка; 3 - лімфоїдні вузлики у м'язовій оболонці; 4 - з'єднання лімфоїдної тканини м'язової та слизової оболонок; 5 - слизова оболонка; 6 - дифузна лімфоїдна тканина слизової оболонки; 7 - крипти. Фарбування гематоксиліном та еозином, $\times 40$

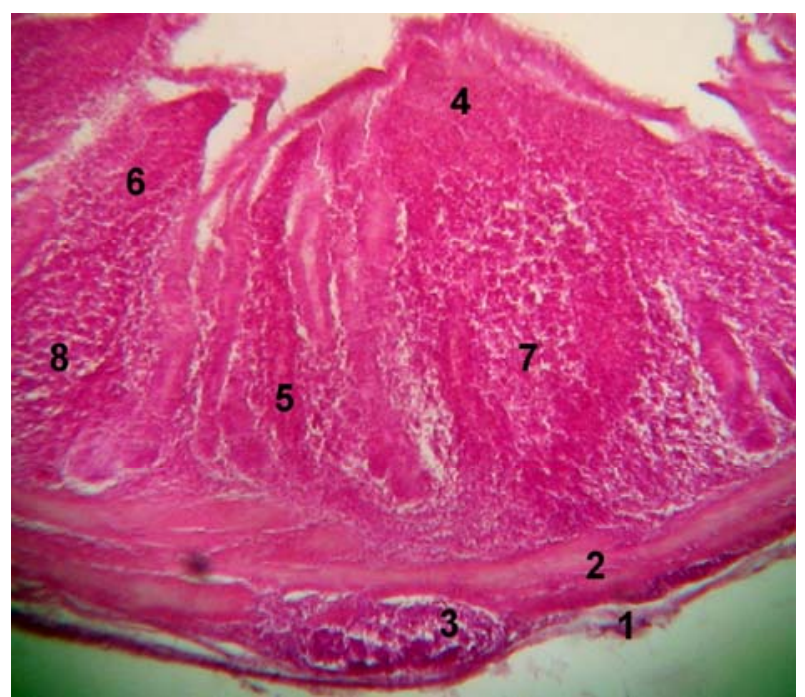

Рис. 4. Стінка дивертикула Меккеля 30-добової качки:

1 - серозна оболонка; 2 - м'язова оболонка; 3 - вторинний лімфоїдний вузлик у м'язовій оболонці; 4 слизова оболонка; 5 - крипта; 6 - дифузна лімфоїдна тканина; 7 - передвузлик; 8 - первинний лімфоїдний вузлик. Фарбування гематоксиліном та еозином, $\times 40$
У стінці сліпокишкових дивертикулів ПП також не виявляються, а ЛТ міститься в слизовій та м'язовій оболонках. У слизовій оболонці вона виявляється у качок всіх досліджених вікових груп. Її площа збільшується до 180-добового віку птиці $(89,02 \pm 1,03 \%)$. У ЛТ слизової оболонки дивертикулів ми виявили тільки три форми ії структурної організації: дифузну і первинні та вторинні ЛВ. ДЛТ реєструється в ЛТ качок усіх вікових груп, ПЛВ - від 5 до 20 діб, а ВЛВ - від 10 до 210 діб. ЛТ в м'язовій оболонці дивертикулів реєструється в качок усіх досліджених вікових груп. Вона представлена ДЛТ, яка виявляється у птиці віком від 1 до 20 діб, і ВЛВ. Останні формуються у качок, починаючи 3 10-добового віку. Цей рівень структурної організації ЛТ у м'язовій оболонці дивертикулів є єдиним у качок віком від 25 до 240 діб. Площа, яку займає ЛТ в м'язовій оболонці дивертикулів, збільшується до 150-добового віку качок.

\section{Висновки}

Лімфоїдна тканина в плямках Пейєра кишечнику, дивертикулі Меккеля і сліпокишкових дивертикулах качок розташована в слизовій і м'язовій оболонках їх стінки. У слизовій оболонці названих структур лімфоїдна тканина виявляється 3 добового віку качок. У м'язовій оболонці плямок Пейєра кишечнику і дивертикулі Меккеля вона виявляється 3 10-20-добового віку качок, а в сліпокишкових дивертикулах - 3 добового.

Повна морфо-функціональна зрілість лімфоїдної тканини плямок Пейєра слизової оболонки кишечнику настає у 15-добовому віці качок, лімфоїдної тканини слизової оболонки дивертикула Меккеля - в 20добовому, а в сліпокишкових дивертикулах - у 10добовому віці. Повна морфо-функціональна зрілість лімфоїдної тканини плямок Пейєра м'язової оболонки кишечнику настає у 15-25-добовому віці качок, лімфоїдної тканини слизової оболонки дивертикула Меккеля - у 25-добовому, а в сліпокишкових дивертикулах - у 10-добовому.

Площа лімфоїдної тканини у слизовій оболонці плямок Пейєра дванадцятипалої і клубової кишки збільшується до 210-добового віку качок, а порожньої кишки - до 150-добового віку. У м'язовій оболонці цих структур лімфоїдна тканина займає найбільшу площу в 150-добових качок. У плямках Пейєра сліпих кишок площа лімфоїдної тканини у слизовій оболонці збільшується до 90-добового віку качок, а в м'язовій до 240-добового. Найбільшу площу лімфоїдна тканина в слизовій оболонці дивертикула Меккеля займає у 20-добових качок, у сліпокишкових дивертикулах - у 180-добових. У м'язовій оболонці цих структур лімфоїдна тканина займає найбільшу площу в 150добових качок.

\section{Бібліографічні посилання}

Kaushansky, K., Lichtman, M.A., Prchal, J. (2015). Williams Hematology, 9th Edition. McGraw Hill Professional. 
Day, M.J., Schultz, R.D. (2014). Veterinary Immunology: Principles and Practice, Second Edition.

Brandtzaeg, P. (1984). Immune function of human nasal mucosa and tonsils in health and disease. Immunology of the Lung and Upper Respiratory Tract. New York, 28-95.

Surjan, L. (1987). Acta oto-laryngol. Stockh. 103, 369379.

Khomych, B.T., Mazurkevych, T.A. (2012). Osoblyvosti topohrafii i budovy plyamok Peyera porozhn'oi kyshky 20-dobovyh kachok [Features of topography and structure of jejunum Peyer's patches in 20-daysold ducks]. Naukoviy visnyk LNUVMBT imeni S. Z. Gzhytskogo - Scientific Bulletin of LNUVMBT named after S. Z. Gzhytskyi. 14, 2(52), 381-386 (in Ukrainian).

Khomych, B.T., Mazurkevych, T.A. (2013). Rost i razvitie Peyerovoy blyashki dvenadtsatiperstnoy kishki u utok v vozraste ot odnih do 120 sutok [Grouth and development of the duodenum Peyer's patch in one-dayold to 120-day-old ducks]. Aktualnye voprosy veterinarnoj meditsiny Sibiri - Topical issues of Veterinary Medicine Siberia. I, 146-149 (in Russian).

Kitamura, H., Sugimura, M., Hashimoto, Y. (1976). Distribution of lymphatic tissues in duck caeca. Jap. J. of Vet. Res. 24 (1-2), 37-42.

Georgescu, B., Ciobotaru, E., Predoi, G., Cornila, N. (2007). Research concerning histostructure of cecal tonsils in some species of domestic birds. Lucrări Stinłifice Medicină Veterinară. XL, 397-404.

Horalskyj, L.P., Khomych, V.T., Kononsky, O.I. (2005). Osnovy histolohichnoi tehniky i morfofunktsionalni metody doslidzhen u normi ta pry patolohii [Fundamentals of histological techniques and morphological methods of investigation in normal and pathological conditions]. Zhytomyr, Polissya Publ. (in Ukrainian).

Avtandilov, G.G. (1990). Meditsinskaya morfometriya [Medical morphometry]. Moscow, Meditsina (in Russian).

Mazurkevych, T.A. (2013). Osoblivosti topografiï i budovy plyamok Peyera porozhnoi kyshky kachok vikom 25-120 dib [Features topography and structure of jejunum Peyer's patches of ducks in age 25-120 days]. Problemy zooinzhenerii ta veterynarnoi medytsyny - Problems of Zooengineering and Veterinary Medicine. Kharkiv, 26, 2, 30-33 (in Ukrainian).

Mazurkevych, T.A. (2013). Morfogenez plyamky Peyera dvanadtsiatypaloi kyshky kachok vikom 25-120 dib [Morphogenesis of the Peyer's patch of the duck duodenum at the age of 25-120 days]. Naukovyi visnyk NUBiP Ukrainy. Seriya «Veterynarna medytsyna, yakist i bezpeka produktsii tvarynnytstva» - Scientific Bulletin of NULES of Ukraine. A series of «Veterinary medicine, quality and safety of animal products». 188, 22-27 (in Ukrainian).

Mazurkevych, T.A. (2014). Morfohenez pliamky Peiiera klubovoi kyshky kachok Blahovarskoho krosu vikom 25-120 dib [Morphogenesis of the Peyer's patch of duck ileum at Blahovarsky cross aged from 25 to 120 days]. Naukoviy visnyk LNUVMBT imeni S. Z. Gzhytskogo - Scientific Bulletin of LNUVMBT named after S.Z. Gzhytskyi. 16, 2(59), 212-218 (in Ukrainian).

Received 28.09.2017

Received in revised form 26.10.2017

Accepted 30.10.2017 